\title{
THE LISTER INSTITUTE OF PREVENTIVE MEDICINE 189|-1966
}

\author{
BY Prof. SiR ASHLEY MILES \\ Director of the Lister Institute
}

The Lister Institute this year celebrates the seventy-fifth anniversary of its incorporation. At the time of its conception the foundations of bacteriology and immunology were being laid in Europe and North America, and the public was beginning to recognize their implications for the prevention and treatment of infective disease. Much of these new sciences had grown from a severely practical need, to exploit for the prevention or cure of infectiou. diseases all relevant features of their microbiology and of the inmune reactions to the causative agent. The technology demanded by this need was not a consequence of the science; it had to grow with it.

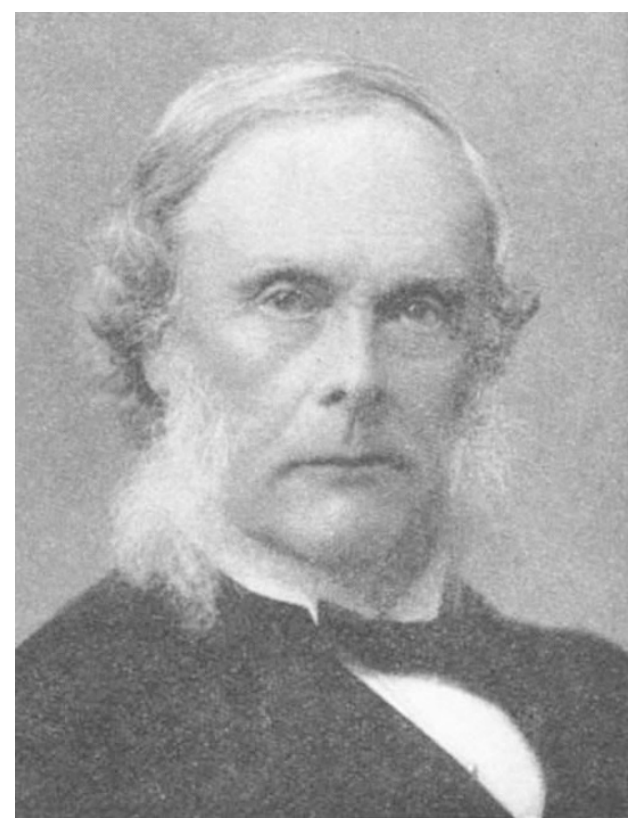

Fig. 1. Lord Lister.

The founders of the Institute in $189 \mathrm{I}$ clearly appreciated the variety of the task in the demands they made of its prospectivo research workers. The Institute was "to study, investigate, discover and improve the means of preventing and curing infective disease of man and animals"; to make and supply "protective and curative materials as have been already found or shall in future be found of value in the prevention or treatment of infective disease"; to provide postgraduate instruction in preventive medicine; and to "treat persons suffering with infective diseases or threatened with them". During its evolution, the Institute has steadily pursued the first two objects, though investigation and discovery have extended well beyond infective diseases. With the establishment of departments of bacteriology elsewhere in the United Kingdom, the teaching duties, except for postgraduate training in research and technology, wer. dropped at the beginning of the century.

The requirement to treat patients was never fulfilled; it reflects the pre-occupation of the founders with the dangers of hydrophobia, and their hope that the new institute would provide the kind of service for the irnmunization of people bitten by rabid animals offered at the then 4 year old Pasteur Institute in Paris. In 1889 th. Lord Mayor of London, Sir James Whitehead, convened a mecting to discuss the prevention and treatment of rabies in the United Kingdom. It was decided not to found a British elinic, but to open a fund for the Pasteur Institute. A gift of $£ 2,000$ was duly made, but some mombers of the committee responsibles felt strongly that Britain should itself have an institute, and suggested the establishment of a Jenner-Pasteur Institute in Cambridge for the study of preventive inoculation and of infective microbes. Within a few months $£ 60,000$ was raised by public appoal, $£ 40,000$ of which was a single donation from a trust with the proviso that the Institute should be in London; and the "British Institute of Preventive Medicine" was duly incorporated on July 25, 1891.

The present site of the Institute in Chelsea Bridge Road was obtained on very generous terms from the Duke of Westminster, and, pending the completion of the building thero, an amalgamation arranged with the College of State Medicine-a private teaching school with aims like that of the Institute and premises in Great Russell Street, where sciontific work began in 1894, under the direction of Armand Ruffer. The Chelsea laboratories were occupied in 1898 .

The name of the Institute was to change twice inore, once in 1898 to the "Jenner Institute", in acknowledg. ment of funds raised at the 1896 centenary of Jenner's discovery of vaccination; and finally in 1903, when a prior claim to the title by an organization called "The Jenner Institute for Smallpox Vaccine" was established, to the "Lister Institute". This last name was a tribute, not only to Lister's eminence in his own field of preventive medicine, but to his close and often decisive associations with the Institute since its inception 14 years before. $\mathrm{He}$ was the first Chairman of the Governing Body, as reconstituted in 1900 . In the same year the Institute was put on a firm financial basis by the first Earl of Iveagh, with a munificent gift of $£ 250,000$ - the beginning of an associa. tion with the Guinness interests that continues to the present day. C. J. Martin became the first Director under the new régime.

\section{Growth}

Since 1900, tho Institute has maintained itself on income from endowments and from the salo of vaccines and antisera, as a private research organization.

Two later dates aro noteworthy. In 1905 the Institute's academic status was recognized by its designation as a school of London University; and in 1913 its seientific 
status was such that a proposal was made by the government to make it the nucleus of a new Department of Medical Research. The proposal, after hot debate by the members of the Institute, was rejected. The government pursued a course that led to tho Medical Research Council and the National Institute for Medical Research; and the Lister Institute was committed to the advantagesand drawbacks - of independence. It has nevertheless since maintained direct relations with both the Council and government departments. In association with the M.R.C. it maintained the National Collection of Type Cultures from 1919 until 1952. In 1946, the Institute, itself a producer of smallpox vaccine for more than 40 years, took over production for the country from the government Lymph Establishment. In the same year, two M.R.C. units, the Blood Group Reference Laboratory and the Blood Group Research Unit, were attached to the Institute at Chelsea; and in 1953, on behalf of the Ministry of Health, the supply of blood productsplasma, gamma globulin and so forth-for the National Health Service was undertaken by a newly established Blood Products Laboratory at Elstree.

The production of "immunologicals" began in 1894 with diphtheria antitoxin, the horses being stabled in and later near London. The production departments acquired their permanent home in 1902, on an estate at Elstree, to which over the years houses, animal quarters and laboratories have been added. Today, the Elstreo laboratories serve the needs of four main departments for research and the production of bacterial vaccines, blood products, therapeutic antisera and virus vaccines. In rocent years, they have produced a dried smallpox vaccine stable onough to last more than 200 years at $50^{\circ} \mathrm{F}$ - the last is an important consideration for material used in the tropics-and have isolated the immunizing antigen of the whooping-cough bacillus in non-toxic form for use, it is hoped, in human beings. Among other vaccines under investigation are a non-infective smallpox vaccine and a rabies vaccine free of the neural antigens that induce encephalitis in the immunized subject.

Tho Chelsea building first housed two departments, for water examination and bacteriology. The first, together with a unit of applied industrial microbiology, soon grew into a department of biochemistry, from which Arthur Harden and W. J. Young published their classical discovery of co-enzyme action in alcoholic fermentation, an achievoment that in 1929 earned Harden a Nobel Prize jointly with von Euler. Among other pioneer contributions of the department are R. Robinson's work on phosphatases and the calcification of bone and W. T. J. Morgan's definition of an endotoxic bacterial antigen as a conjugate of protein and lipopolysaccharide.

After the Second World War tho biochemical interests shifted to the chemistry of the substances that determine the immunological properties of the different groups of human red blood cells, which were identified as macro. molecular glycoproteins, and now centre on the genetic control of their biosynthesis. The interest in polysac. charides is also reflected in researches on the biosynthesis and metabolism of starehes and glycogen; and there was a renewal of fundamental work on co-enzymes, on this occasion pyridoxal phosphate and co-enzyme $A$. The department now has a team working on the lipid chemistry of mammalian cell membranes and their relation to the function of normal and tumour cells.

The studies begun in the Department of Bacteriology ranged widely over microbial infection-not only in terms of the causal agents-protozoa, bacteria and virusesbut of their pathology and epidemiology, and the vaccines and antitoxins for their prevention and cure. In collaboration with the Royal Society, plague was tackled by the Institute when, in 1905-8, the Plague Commission in India, under C. J. Martin's direction, proved that the rat flea was a carrier of the plague bacillus. Departments of entomology and protozoology were created for work on fleas and lice and on trypanosomes, the life cycle of which was studied in rats and fleas by E. A. Minchin in Britain and in cattle and tsetse flies by Muriel Robertson in Uganda. Another pioneering contribution to epidemiology and, indeed, to oxperimental medicine. was tho ereation in 1909 of a department of statistics led by Major Greenwood. The last three departments no longer exist, though the interest in epidemiology and tropical diseases is maintained in still continuing researches on the blood meals of insect vectors of trypanosomiasis and malaria, and on the immunopathology of trypanosomiasis.

The study of viruses and rickettsiac fourished in the twenties and thirties under J. C. Ledingham (who succeeded Martin as Director in 1931) and was resumed afte. the Second World War. A separate Department of Virology was created in 1952 , to which the M.R.C. Trachoma Research Unit was attached in 1955 . The Unit now studies the immunopathology of experimental trachoma infections and, at field stations in the Gambia and Iran, the epidemiology of trachoma and the efficacy of vaccines against the disease.

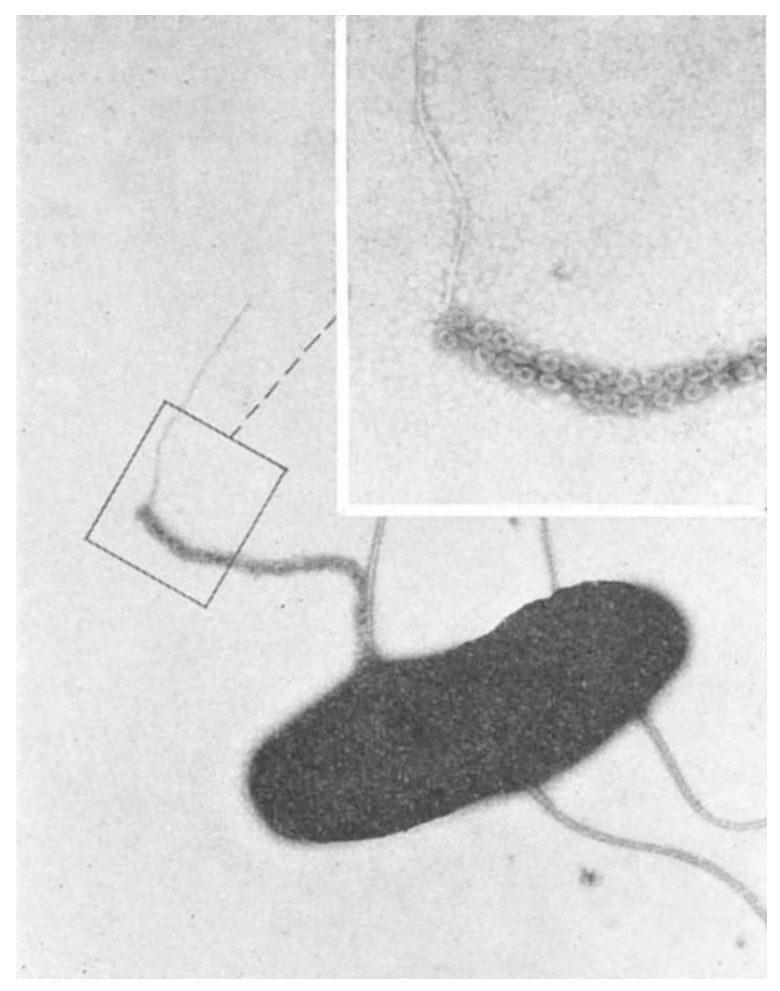

Fig. 2. A male $\left(F^{\prime}+\right)$ bacterium, bearing flagella and another appendage. the $\boldsymbol{F}$ pilus, which is probably the conjugation organ. 'This pilus is known to adsorb $F$-specilic phages, of which two are shown here; a spherical phage (MS2) along the length of the $F$ jilus and a fllamentous phage $(M 13)$ on its tip $(\times 28,000$; inset 84,000$)$. Recent work at the Lister Institute shows that similar pili are formed by certain antibiotic resistant hacteria, and presumably provide the means by which their resistance is passed on to antibiotic-sensitive strains.

The 1920 s saw three major contributions to bacterio$\operatorname{logy}$ : J. A. Arkwright's discovery of $S \rightarrow R$ variation in the typhoid bacillus, whereby the characteristic coll-wall constituent associated with virulence and immunizing power is lost; A. Felix's discovery of al highly mousevirulent variant of the bacillus with an extra cell-wall antigen; and Emmy Klieneberger-Nobel's work on another typo of bacterial variant, the $L$.form, which cannot synthesize a rigid coll wall. The First World War stimulated work on the proper identification of the thon ill-understood bacilli of gas gangrene, done in Paris by 
Muriel Robertson; and the Second World War, work on the toxins of one of these bacilli, $\mathrm{Cl}$. welchii, which lod to the first identification of a bacterial exotoxin as an enzyme, by Marjorie Macfarlane and B. C. J. G. Knight. In 1953, the Guinness-Lister Unit for microbiology was established, which, among distinguished work on bacterial physiology and inheritance, defined the genes involved in Arkwright's $S \rightarrow R$ mutation. The current rescarch of the Unit is directed towards the dynamics of microbial infections, the antigenic structure of mycoplasma and, with the recently established electron microscope unit, the correlation of physiological activities with the ultrastructure of bacteria.

From 1903 to the present day, the Institute tackled a wide varioty of problems in experimental pathology. For example, it co-operated with the Navy in a study of physiological adaptation to altered atmospheric pressures, which resulted in reform of the methods of preventing accidents and caisson disease during diving operations. During the First World War, when beriberi and scurvy appeared in troops overseas, a team was formed to investigate the nature and distribution in foods of the two vitamins concerned; and immediately after the war. the team, now a Nutrition Department that included Harriette Chick and Margaret Hume, collaborated with the M.R.C. in work on rickets and scurvy among the peoples of central Europe. In Vienna they contributed substantially to the proof that vitamin $D$, or stimulation of its synthesis in the sufferer by sunlight or ultra-violet irradiation, would cure rickets.

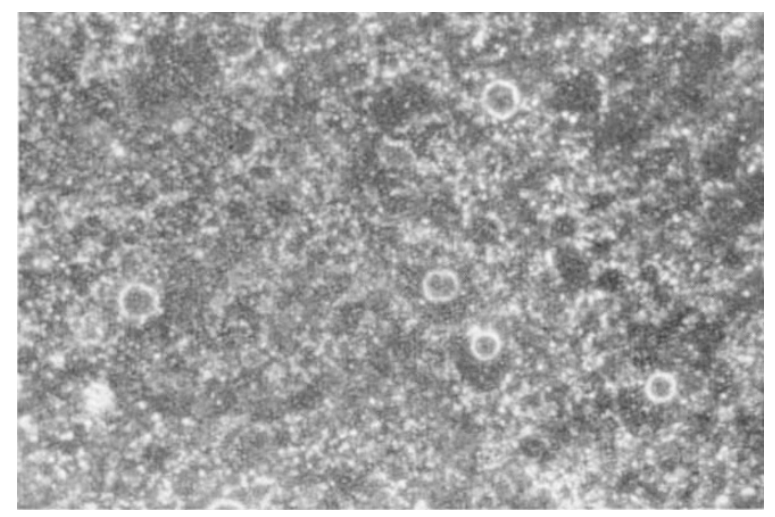

Eig. 3. When stained with Giemsa and viewed by dark fleld illumination, trachoma elementary bodies appear as small bright particles; this technicue was devised at the Lister Institute for their rapid recognition and enumeration. The five large objects are red blood corpuscles (chick embryo yolk sac smear $)(\times 800$. $)$

In the inter-war years, work on diseases duo to doficiency of vitamins solublo in wator continued, and in the Second World War the department established the distribution of vitamins in wheat grain, with results that led to the 85 per cent extraction rate of grain for the wartime whole. meal loaf. The nutrition department ceased to exist soon after the war, but the Departmont of Experimental Pathology was ro-established in 1952 with interests in non-specific immunity to infection, the biochemical mediators of inflammation, and the allergies of man.

The Department of Biophysics was built at Chelsea in 1936, to house a Svedberg ultracentrifuge and a Tiselius electrophoresis apparatus. Theso instruments, the first of their kind in the country, were applied by A. S. McFarlane both to the characterization of viruses and to the proteins, including the immunoglobulins, of plasma. The technical facilitios of the department proved to be essential in 1939-45, when the wartime demand for plasma for transfusion was met by devising methods of providing it. The work culminated in R. A. Kekwick's system for the separation and purification of clinically useful proteins of human plasma. Under the guidance of A. N. Drury. who became Director in 1942, the increasing call for such materials after the war lod to the establishment of th" Blood Products Laboratory at Elstree, where out-dated blood from Transfusion Centres is treated to provide substances such as albumin, fibrinogen, thrombin, antihaemophilic globulin and immunoglobulin.

At Chelsea, the biophysical work now centres on bio. logically important plasma proteins-immunoglobulins. and others-and macromolecules, such as glycoprotein: and polysaccharides, under collaborative study with other departments.

\section{Today}

The Institute has had a chequered career, especially. in its early days, and it has engaged in a wide varjety of scientific activities. Its growth, however, has been by no means haphazard. As a matter of conscious policy the direction has been flexible enough to allow most of its researches to be chosen ad hominem, and the men hav" been free and ready enough to accept problems from the. outside that suited their skills and predilections. 'Th" flexibility is expressed, too, in a readiness to creat. departments and to let them vanish when the problems were solved or the momentum slackened. There has always bcen stimulating interplay and collaboration between departments at Chelsea and Elstree, whether production departments or other; and often a full-tim research worker has moved to part-time production anct vice versa.

These policies have undoubtedly contributed to the Institute's success-and in at least today's climate of opinion are accounted as virtues, especially in the closi. relation of research and teohnology. The staff of the production departments are appointed primarily as research workers who, from recent postgraduates upwards. are free if they wish to tackle problems with no direct relation to production, a condition with the same all-round beneficial effect as active research in a teaching department. Moreover, when the research is in the same field as production, it can be, and often is, pursued much mor. intensively than could be justified by increased produe. tivity or the immediate promise of a new product.

By modern standards the Institute is small. Except. during the Second World War, the number of graduat, scientists since 1930 has been about sixty; at present they are divided between twelve departments. The Chelsea departments are biochemistry, biophysics, elec. tronmicroscopy, experimental pathology, microbiology and virology, five of them with professorial heads and the last with an attached M.R.C. unit; and two other M.R.C. units dealing respectively with the immunological and genetic aspects of blood groups. Three of tho four research and production departments at Elstree are concerned with vaccines and antisera, and one with blood products.

This spread over a diversity of activitios is not so thin as might at first appear, because the major activities of both Chelsea and Elstree, though widely diversified, have enough in common in intellectual and technical attack to provide fruitful cross-fertilization of ideas and methods.

It will be evident from the forogoing that two themes predominate. The first, infective disease, is developed in work which, ranging as it does from microbial ultrastructure to the immunology and pathology of the infected host, from viruses to protozoa, and from tho immuno. chemistry and physical chemistry of antibodies and microbial antigens to the production and fiold trials of vaccines, admirably maintains the research traditions built up in fulfilling the demands of the Institute's founders set out at the beginning of this article. These demands are as valid today as they were in 1891 and, as 
in the past, are roalized in work that goes far beyond the research laboratories. In the United Kingdom there is collaboration with clinicians, public health authorities and research councils. Abroad the Institute works with the World Health Organization, particularly in helping to start production of vaccines in Africa, the Middle. and Far East and in training their graduates in production mothods; and engages in cpidemiological and immunization studies in Africa and the Middle East.
It has achieved much as a small establishment; but with the increasing complexity of biological research, it is faced with the need for accelerating its present rate of providing the necessary new skills and instrumentation. It hopes, too, to build accommodation for the staff needed to make its existing departments optimally effective, and for new departments. A department of experimental immunology is needed, to which some of the current work could be assimilated, the main task of which would be the
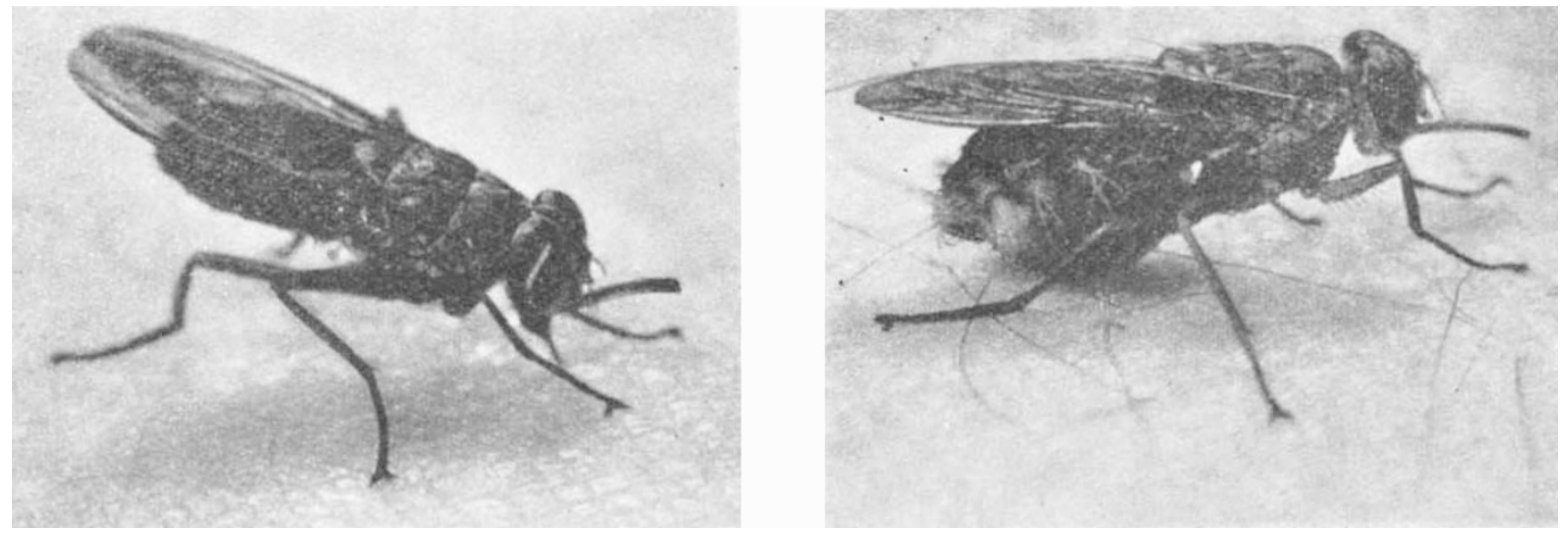

Fig. 4. Tsetse fly (Glossina austeni) before and after a blood meal. In the wild tsetse fly, the species of animal host recently fed on can be precisely identified by serological tests on the dried stomach contents of the engorged fly.

By reason of its implications in proventivo medicine, the introduction some 25 years ago of the second theme, blood, would assuredly have won the approval of the founders, as both a theme and its variations. If the work of the two M.R.C. units is included-an inclusion justified by their long and closo association with the Institute's work-these range from the immunochemistry and molecular structure of plasma proteins and blood-group glycoproteins, through blood-group serology and genetics to the isolation of therapeutic blood substances.

This unity in diversity is not maintained by any doctrinaire embargo on other territories for exploration; lipid biochemistry, for example, now actively applied to mammalian cells, grew from an investigation of the mode of action of the exotoxins of gas gangrene bacilli. The Instituto is prepared for any diversity it can afford and accommodate.

\section{The Future}

The Institute is justifiably proud of its achievements for British science, and of having made them by its own financial efforts. It receives public money from research councils, governmental bodies and the like for specified pieces of research work; but none as a school of the University, because its formal teaching is restricted to Ph.D. students. It has also benefited greatly by the generosity of private persons, private foundations and the like. 'The larger part of its income, however, depends on the work of its production departments and, to a lesser extent, on its endowments.

The Institute was once uniquo in the country, but medical research establishments set up since that time have evolved a very similar pattern of work. It differs, however, from most in its independence and in the degree to which it combines fundamental and applied research with technology. These are differences which the Governing Body, and indeed other people in the world of science, strongly believed to be worth preserving for the Institute's finture'. exploration by the newer techniques of the immuno. pathology of infection and immunization-an aspect of the matter which tends to be regarded as the outmoded precursor of the immunology of today.

It would be unrewarding and presumptuous further to forecast the Institute's future; unrewarding because of the uncertainty of all forecasting and presumptuou. in the light of the Institute's tradition of going where the ideas of its scientists lead. Given the financial means of survival, the future course of the Institute will be con. strained only by a liberal interpretation of the founders directive "to study, investigate, discover and improv". the means of preventing and curing (infective) disease of man and animals".

"Sir Joseph Lister must indeed experience a glorious feeling of deepest satisfaction when he surveys the labours of his life. His work is accomplished and brought to an incomparable conclusion. He has conquered and attained his object. When we but compare the surgery of thirty years ago, before Lister appeared on the scene. with that of today, what a change we see ! We can scarcely. carry ourselves back in imagination to the pre-antiseptic days of surgery, but each one who has known the older state of things from personal experience cannot fail to realize with fuller understanding and livelier joy how great a blessing Lister is to suffering humanity. . . . The word surgery in its origin signifies a handicraft; but that which was thus manual at first has become an art and a science which has, thanks above all to Lister, raised itself with impetuous and surprising speed in the last twenty years to a previously unknown height of development. Modern surgery no longer stops short at the exterior, but has gone oven deeper, and now includes within the sphere of its activity every organ of the human body without exception. And for this mankind is indebted in the first place to Sir Josoph Lister. As far as there is an earthly immortality it must be his, for as long as ever surgery is scientifically discussed his name cannot fail to be mentioned."

H. Tillmans, Nature, 54, 1 (1896). 